\title{
The Prevalence of $\boldsymbol{H}$. Pylori $\operatorname{cag} \boldsymbol{A}$ Gene in Patients with Gastric Ulcer
}

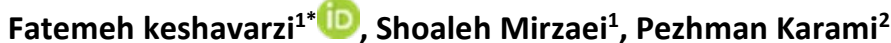

1. Department of Biology, Sanandaj Branch, Islamic Azad University, Sanandaj, Iran

2. Department of Medical Microbiology, Faculty of Medicine, Hamadan University of Medical Sciences, Hamadan, Iran

$10.30699 / \mathrm{ijmm} \cdot 15 \cdot 3 \cdot 345$

\section{ABSTRACT}

Background and Aim: Helicobacter Pylori (H. pylori) is one of the reasons for the gastric inflammation and peptic ulcers. It is a predisposing factor of gastric adenocarcinoma. Cytotoxin $A$ encoded by the cagA gene is one of the major virulence factors in bacterial pathogenicity, which is of special importance due to genetic diversity in different geographical areas. The purpose of this study was to evaluate the prevalence of the cagA gene in the patients suffering from gastric ulcers.

Materials and Methods: Seventy-five paraffin blocks of stomach biopsy samples from patients infected with $\mathrm{H}$. pylori and suffering from gastric ulcers were randomly evaluated in the province of Kermanshah in the spring of 2016, Iran. DNA samples extracted by the boiling method were investigated using PCR by the use of particular primer pairs for a protected area in the $g / m M$ gene, and the existence of the $\operatorname{cag} A$ gene.

Results: From the 75 samples, 56 cases (\%74.66) were glmM-positive and among them, 39 cases (\%69.64) tested positive for cagA gene. Comparing patients in terms of gender, the frequency of the cagA gene was $22(\% 39.28)$ and 17 (\%30.35) in males and females, respectively. Finally, comparing patients in terms of age, 16 cases (\%21.33) were younger than 40 years old and 23 cases (\%41.07) were older than 40 years old.

Conclusion: The results of this study showed significant association between the frequency of the cagA gene and peptic ulcer in the studied patients.

Keywords: CagA gene, Gastric ulcer, GImM gene, H. Pylori

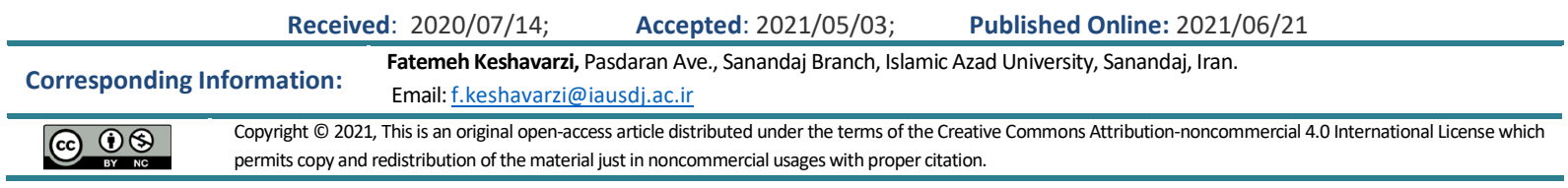

Use your device to scan and read the article online

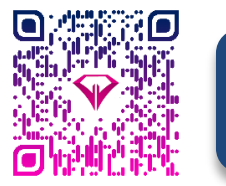

keshavarzi F, Mirzaei SH, Karami P,. The Prevalence of H. Pylori cagA Gene in Patients with Gastric Ulcer. Iran J Med Microbiol. 2021; 15 (3) 345-351

\section{Download citation: BibTeX | RIS | EndNote | Medlars | ProCite | Reference Manager | RefWorks}

\section{Send citation to: $\$ \underline{\text { Mendeley }} \mathbf{Z}$ zotero $\overline{\text { RefWorks }}$}

\section{Introduction}

Gastric Ulcer is a painful injury in the internal gastric wall or the initial part of the small intestine. There is no clear reason for the gastric ulcers. Today, it is evident that gastric ulcer is due to an imbalance of gastric and duodenal ulcers. The main bacterium involved in gastric ulcers is Helicobacter Pylori $(H$. pylori) (1-4).
H. pylori is a gram-negative and spiral-shaped bacillus. The size of this bacterium is around $0.3 \times 5.5$ micrometers. These bacteria are colonized in the human stomach epithelium and most of the other animal species. They have an important role in pathogenicity of gastric inflammation, gastric ulcer, and gastric cancer. They are also etiologically 
important in the illnesses of peptic ulcer and malignant stomach (5-7).

Antrum mucus, exotic, and cardia are equally sensitive to infection and the bacteria are colonized in the same way (8). The bacteria of $H$. pylori are colonized in the stomach of half of the population in the world. Tissue gastritis is a public complication among all individuals infected with these bacteria; however, it has evident clinical circumstances similar to gastric ulcer and gastric cancer just among a few of the patients (5-9).

The mechanisms responsible for different stages of the disease are not fully understood. However, two pathogenicity indices have been identified which have been introduced as virulence factors of different bacterial strains (10-11). These factors are cytotoxinassociated gene $A(\operatorname{cag} A)$ and vacuolating cytotoxin (vacA) (12-14).

The $\operatorname{cag} A$ gene is located in the region of $I$ in the pathogenicity part $(\operatorname{Cag} A, P A I \operatorname{Cag} A)$ and is one of the leading causes of pathogenicity. Cag $P A l$ is a $40 \mathrm{~kb}$ locus and its percentage of guanine-cytosine (35\% to $39 \%$ ) is different from the other genomes (8) and is transmitted through some strains of $H$. pylori. This island has 31 genes out of which, 6 are coding the fourth type of secretion system and take the role in the association of the host bacteria with the pathogenicity process (1-10).

CagA is a $120-145 \mathrm{kDa}$ protein encoded on the 40 $\mathrm{kb}$ cag pathogenicity island (PAI). The cagA protein is one of the superficial proteins of the external membrane in $\mathrm{H}$. pylori that has great power in raising the safety. The products of this gene cause duckling in the host cell, after entering bacteria to the stomach epithelial cells. The cagA protein can increase the virulence of bacteria after entering the target cell directly and interference with the cell messaging systems. The existence of this gene in some strains of $H$. pylori shows the existence of such pathogenicity island of cag PAI (6-9).

H. pylori strains can be divided into cagA-positive or -negative strains. It seems that the severity of digestive illnesses such as peptic ulcer, gastric mucosal atrophy, and gastric cancer is because of $H$. pylori relating to cag pathogenicity island such as peptic ulcer (1-15). Also, studying the specific bacterial genes of $g / m M$ was used to prove, control, and study the existence of $H$. pylori. According to the previous studies, the $\mathrm{g} / \mathrm{mM}$ gene had more sensitivity to recognize these bacteria in comparison with the other genes (10). Therefore, the purpose of the present survey was to study the frequency of the cagA gene of $H$. pylori gene among the patients suffering from gastric ulcers in the City of Kermanshah.

\section{Materials and Methods}

\section{Samples}

The present research was a case-observing study. The samples were 75 PA paraffin blocks; 40 men $(47 \pm 28)$ and 35 women $(47 \pm 26)$ of the patients suffering from gastric ulcer that were randomly collected from Imam Reza Hospital in the City of Kermanshah, Iran. Participants in research clearly expressed consent to being involved in the study. Then, the information related to each patient was collected from the registered Office of Pathology in the Hospital.

Selecting the patients was performed randomly, and the only inclusion criterion was gastric ulcer.

\section{DNA Extraction}

DNA extraction was done by the boiling method according to the Protocol. Then, genomic DNA samples $(4 \mu \mathrm{L})$ mixed with diluted loading dye $(2 \mu \mathrm{L})$ were electrophoresed on $1.5 \%$ agarose gel.

\section{Measuring DNA Concentration}

The optical absorption of extracted DNA samples was measured by NanoDrop (2000/2000C, Thermo, USA) using a ratio of OD260/OD280 to ensure the desired quality of DNA to be used in PCR.

\section{Molecular Studies}

The primers sequences to amplify the $\mathrm{g} / \mathrm{mM}$ gene were selected from a previous study (16) and primers for the $\operatorname{cagA}$ gene were designed by Gene Runner software considering all the points of SNP. To ensure the accuracy of the primers, they were blasted in NCBI database (Table 1). Primers were synthesized by Cinnagen Company (Iran). Molecular study was performed by PCR method using the PCR detection Kit (Cinnaclon). The PCR cycles of the desired genes are presented in Table 2, separately.

Table 1. The primers sequences

\begin{tabular}{|c|c|c|c|}
\hline Primer name & Primer sequence & $\begin{array}{l}\text { Primer connection } \\
\text { temperature }\end{array}$ & Length of the piece \\
\hline $\begin{array}{l}\text { glmM-F } \\
g \operatorname{lm} M-R\end{array}$ & $\begin{array}{c}\text { AAGCTTTTAAGGGGTGTTAGGGGTTT } \\
\text { AAGCTTACTTTCTAACACTAACGC }\end{array}$ & 58 & $294 b p$ \\
\hline $\begin{array}{l}\operatorname{CagA}-F \\
\operatorname{CagA}-R\end{array}$ & $\begin{array}{c}\text { TTGACCAACAACCACAAACCGAAGC } \\
\text { TTCCCTTAATTGCGAGATTCC }\end{array}$ & 55 & $183 \mathrm{bp}$ \\
\hline
\end{tabular}


Table 2. PCR proliferation conditions

\begin{tabular}{|c|c|c|c|c|c|}
\hline \multicolumn{6}{|c|}{ Cycling condition } \\
\hline Genes & Initial denaturation & Denaturation & Annealing & Extension & Final Extension \\
\hline \multirow{2}{*}{$g \operatorname{lm} M$} & $94{ }^{\circ} \mathrm{C}$ & $94{ }^{\circ} \mathrm{C}$ & $58^{\circ} \mathrm{C}$ & $72{ }^{\circ} \mathrm{C}$ & $72^{\circ} \mathrm{C}$ \\
\hline & $5 \mathrm{Min}$ & $30 \mathrm{Sec}$ & $60 \mathrm{Sec}$ & $30 \mathrm{Sec}$ & $5 \mathrm{~min}$ \\
\hline \multicolumn{6}{|c|}{ Repeated for 35 Cycles } \\
\hline \multirow[t]{2}{*}{$\operatorname{cag} A$} & $94{ }^{\circ} \mathrm{C}$ & $94{ }^{\circ} \mathrm{C}$ & $55^{\circ} \mathrm{C}$ & $72{ }^{\circ} \mathrm{C}$ & $72{ }^{\circ} \mathrm{C}$ \\
\hline & $5 \mathrm{Min}$ & $30 \mathrm{Sec}$ & $30 \mathrm{Sec}$ & $30 \mathrm{Sec}$ & $5 \mathrm{~min}$ \\
\hline \multicolumn{6}{|c|}{ Repeated for 35 Cycles } \\
\hline
\end{tabular}

\section{Statistical Analysis}

The data were analyzed by Excel software and SPSS 20 (SPSS Inc., Chicago, III., USA) and frequency of the genes were studied. Also, the logistic regression test was used to determine the association of each form of the disease with the virulence genes alone. A Pvalue $<0.05$ was considered statistically significant.
The electrophoretic patterns of The PCR products of glmM and cagA genes were presented in Figures 1 and 2 , respectively. The length of amplified fragments related to g/mM and cagA genes are 294 and $183 \mathrm{bp}$, respectively. After confirming glmM-positive samples, which indicate the presence of $H$. pylori, these samples were used to monitor and determine the presence of $\operatorname{cagA}$ gene.

\section{Results}

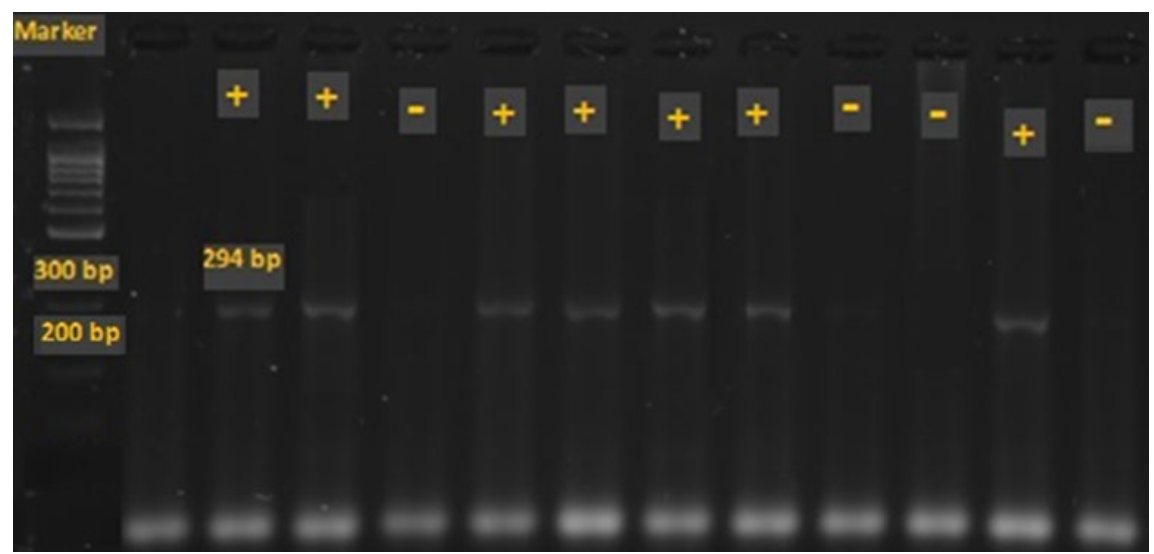

Figure 1. The electrophoretic pattern of the PCR product of glmM gene. The length of amplified fragment by glmM primers is $294 \mathrm{bp}$. The first column shows the ladder of $100 \mathrm{bp}$. The samples of 2, 3 and 5-8 and 11 are positive for $\mathrm{g} / \mathrm{mM}$ and 1, 4 and 9, 10, 12 are negative for this gene.

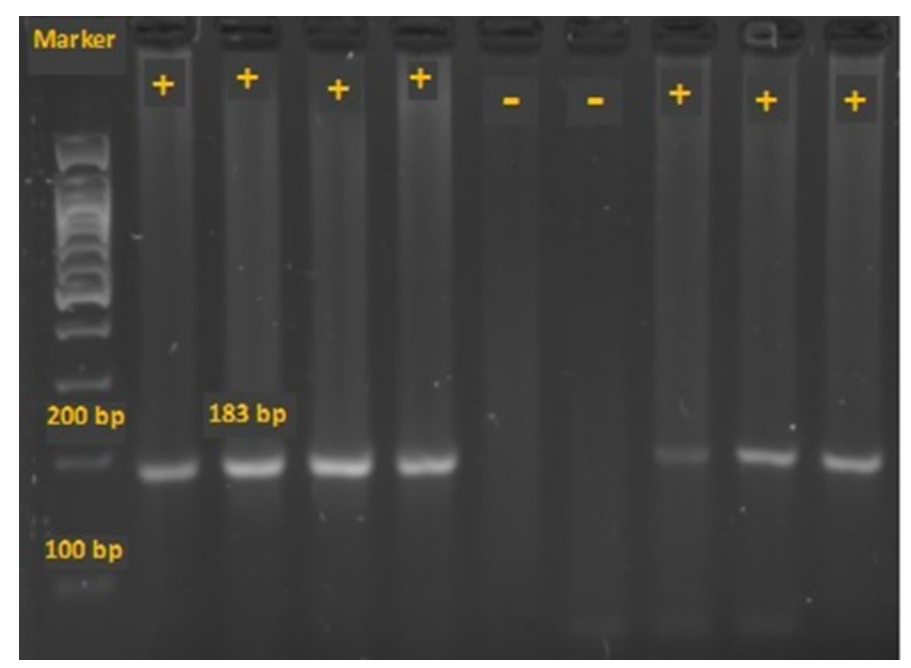

Figure 2. The electrophoretic pattern of the PCR product of the cagA gene. The length of amplified fragment by cagA primers is 183 bp. The first column shows the ladder of $100 \mathrm{bp}$. The samples of 1,2,3 4 and 7,8,9 are positive for cagA and 5 and 6 are negative for this gene. 
The results showed that out of 75 samples, 56 were positive for $\mathrm{g} / \mathrm{mM}$ gene and out of 56 positive samples (glmM-positive), 39 (69.64 \%) were positive for cagA gene.

Among them, the frequency of $\mathrm{g} / \mathrm{mM}$ gene was more in men $(29,38.66 \%)$ compared to women (27, $36 \%)$, although not significant. Also, regarding cagA gene, its frequency was more in men $(22,39.28 \%)$ compared to women $(17,30.35 \%)$ but not significant (Table 3) (Figure 3).

The correlation between the clinical forms of the disease and the presence of $\mathrm{g} / \mathrm{mM}$ and $\operatorname{cagA}$ genes was found to be significant $(P=0.005)$.

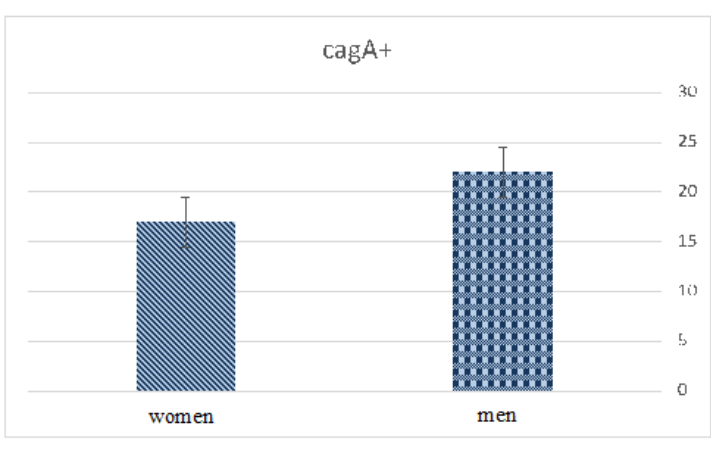

Figure 3. Comparing the frequency of positive cagA gene

Table 3. Comparing the frequency of positive $g / m M$ and CagA genes

\begin{tabular}{|lllll|} 
& GlmM+ & GlmM- & CagAt & CagA- \\
\hline $\begin{array}{l}\text { Patients } \\
\text { N=75 }\end{array}$ & $56(74.66 \%)$ & $19(25.33 \%)$ & $39(69.64 \%)$ & $17(30.35 \%)$ \\
\hline $\begin{array}{l}\text { Man } \\
\mathbf{4 0}(53.33 \%)\end{array}$ & $29(38.66 \%)$ & $11(14 \%)$ & $22(39.28 \%)$ & $7(12.5 \%)$ \\
\hline $\begin{array}{l}\text { Woman } \\
\mathbf{3 5}(\mathbf{4 6 . 6 6 \% )}\end{array}$ & $27(36 \%)$ & $8(10.6 \%)$ & $17(30.35 \%)$ & $10(17.85 \%)$ \\
\hline
\end{tabular}

The study of $\mathrm{g} / \mathrm{mM}$ gene among women and men indicated that 23 patients (30.66\%) under 40 years old, and 33 patients (44\%) over 40 years old tested positive for glmM gene that shows the frequency of this gene is more among patients who were over 40 years old. Also, about cagA gene, 16 patients (21.33\%) under 40 years old and 23 patients $(41.07 \%)$ over 40 years old were positive for the cagA gene that shows the frequency of this gene is higher in the patients over 40 years old (Table 4 ).

Also, the relation between age and sex of the patients with clinical forms of $H$. pylori disease was studied using Chi-square and Fisher's exact tests. No significant association was found in this regard.

Table 4. Comparing the frequency of the positive g/mM and cagA genes among people with the age around 40 years old.

\begin{tabular}{|cccc|}
\hline Patients & GlmM+ & GlmM- & cagA+ \\
\hline $\mathbf{N}=\mathbf{7 5}$ & $56(74.66 \%)$ & $19(25.34 \%)$ & $39(69.64 \%)$ \\
\hline Less than $\mathbf{4 0}$ & $23(30.66 \%)$ & $11(14.64 \%)$ & $16(28.57 \%)$ \\
\hline More than 40 & $33(44 \%)$ & $8(10.70 \%)$ & $23(41.07 \%)$ \\
\hline
\end{tabular}

\section{Discussion}

In this research, 75 paraffin blocks of stomach biopsy samples from the patients infected with $H$. pylori and suffering from gastric ulcers were investigated in the province of Kermanshah, Iran. Also, the extra information about these patients was achieved through registered Office of Pathology, Imam Reza Hospital.

The glmM gene, which has more sensitivity for $H$. pylori detection compared to the other genes, was used to identify positive $H$. pylori samples (10-11). Out of 75 samples, 56 (74.66\%) were positive for the $\mathrm{g} / \mathrm{mM}$ gene that indicates the high frequency of $H$. pylori among patients suffering from gastric ulcer that was in line with the previous studies outcome (8).

In the study of Megrow et al., the prevalence of $H$. pylori or the prevalence of $\mathrm{g} / \mathrm{mM}$ gene in the biopsy specimens was $44 \%$ (12). In g/mM-positive samples, the prevalence of cagA was $69.64 \%$ (39), indicating a high frequency of this gene in these samples. In previous study by Jafari et al., on 280 gastric biopsy samples in Tehran, the frequency of the cagA gene was about $74.3 \%$ (13).

The prevalence of the cagA gene in the studies of Douraqi and Crashia were $84.02 \%$ (2) and $41.5 \%$ (14), 
respectively. These results were different from the previous studies in Europe (66-73\%) but identical with the majority of studies in Middle East countries (Turkey, Egypt, Israel, and Jordan) in which the outbreak of the cagA gene was between 26 to $44 \%$ (7).

In another study by Hussein et al., the frequency of the $\operatorname{cag} A$ gene was $65.9 \%$ along with achieved results from gathered samples over the same gene in Tunisia (61.6\%), Iran (76\%), and Iraq (71\%) (15), and was similar to the results of the present study. In the study by Essawi et al., which was conducted to recognize the existence of $H$. pylori in biopsy samples through PCR, the frequency of this gene was $65.9 \%$ (16) that accords with my results.

Then, the patients were studied and compared based on the gender. The findings showed the frequency of cagA gene in man at 22 (39.28\%) and in women at $17(30.35 \%)$. The frequency of the cagA gene was more in men compared to women. It seems that high number of men samples or having more exposure of men to infection or even the gender and some other factors might be effective.

The patients were also compared in terms of their age. The results showed that the level of cagA gene frequency in the patients under 40 was 16 (21.33\%)

\section{Referance}

1. Yu C, Li L, Chen W, Jiao Y, Yang N, Yang E, Zhang J, Chen L, Li Y. Levofloxacin susceptibility testing for Helicobacter pylori in China: comparison of E-test and disk diffusion method. Helicobacter. 2011; 16:119-23. [DOI:10.1111/j.15235378.2011.00820.x] [PMID]

2. Ayala G, Escobedo-Hinojosa WI, de la Cruz-Herrera CF, Romero I. Exploring alternative treatments for Helicobacter pylori infection. World J Gastroenterol 2014; 20:1450-69. [DOI:10.3748/wjg.v20.i6.1450] [PMID] [PMCID]

3. Yamaoka Y, Kato M, Asaka M .2008. Geographic differences in gastric cancer incidence can be explained by differences between Helicobacter pylori strains. Intern Med 47: 1077-83. [DOI:10.2169/internalmedicine.47.0975] [PMID] [PMCID]

4. Polk DB, Peek Jr RM. Helicobacter pylori: gastric cancer and beyond. Nat Rev Cancer 2010; 10:403-14. [DOI:10.1038/nrc2857] [PMID] [PMCID]

5. Mendoza JA, Weinberger KK, Swan MJ. The Hsp60 protein of Helicobacter pylori displays chaperone acactivity under acidic conditions. Biochem Biophys Rep2017;

9:95-9. and in the patients over 40, was 23 (41.07\%). This determines that the frequency level of this gene among patients over 40 years old is higher. Thus, the frequency of $\operatorname{cag} A$ gene is higher among people over 40 years because of the existence of these bacteria among the elder patients.

\section{Conclusion}

In the present study, the frequency of the $\operatorname{cag} A$ and glmM genes was investigated in the patients with gastric ulcer in the province of Kermanshah. The results showed high level of $\mathrm{g} / \mathrm{mM}$ gene in the studied patients. Therefore, $H$. pylori infection is probably an effective factor to cause gastric ulcer in these patients. Also, the high abundance of cagA gene emphasizes the pathogenicity of this gene in positive $H$. pylori patients. Therefore, monitoring this gene is important in assessing the possibility of gastric ulcer disease.

\section{Acknowledgment}

The authors would like to thank the personnel of Imam Reza hospital in Kermanshah.

\section{Conflict of Interest}

The authors declared that they have no competing interests.

\section{[DOI:10.1016/j.bbrep.2016.11.011] [PMCID]}

6. Prasertpetmanee S, Mahachai V, Vilaichone RK. Improved efficacy of proton pump inhibitor amoxicillin - clarithromycin triple therapy for Helicobacter pylori eradication in low clarithromycin resistance areas or tailored therapy. Helicobacter. 2013; 18:270-3. [DOI:10.1111/hel.12041] [PMID]

7. Atherton JC, EM Omar-El, JL Hale, RH A. In Differences. at motif phosphorylation tyrosine CagA pylori $\mathrm{H}$ on influences and, strains Asian East and western between. Microbiol Med J 2008; 7(10): 57 62.

8. Thung I, Aramin H, Vavinskaya V, Gupta S, Park JY, Crowe SE, Valasek MA. Review article: the global emergence of Helicobacter pylori antibiotic resistance. Aliment Pharmacol Ther. 2016;43:51433. [DOI:10.1111/apt.13497]

9. Pellicano R, Ribaldone DG, Fagoonee S, Astegiano M, Saracco GM, Mégraud F. A 2016 panorama of Helicobacter pylori infection: key messages for clinicians. Panminerva Med. 2016;58:304-17. 
10. Falsafi T, Ehsani A, Niknam V. The role of active efflux in antibiotic - resistance of clinical isolates of Helicobacter pylori. Indian $\mathrm{J}$ Med Microbiol. 2009;27:335-40. [DOI:10.4103/02550857.55452] [PMID]

11. Abolghasem Tohidpour. CagA-mediated pathogenesis of Helicobacter pylori, Microb Pathog $93 \quad$ (2016) 44e55. [DOI:10.1016/j.micpath.2016.01.005] [PMID]

12. Megraud FM and Lehours P. "Helicobacter pylori detection and antimicrobial susceptibility testing," Clini Microbiol Rev. 2007; 20(2): 280-322. [DOI:10.1128/CMR.00033-06] [PMID] [PMCID]

13. Jafari F, Aslani M, Shokrzadeh L, Baghai K, Dabiri H, Zojaji H, Razavilar V, Kharaziha P, Haghazali M, Molaei M, Zali MR. Distribution of UreC, CagA, and vacA genes in Helicobacter pylori isolated from patients with gastroduodenal disease in Tehran, Iran. Europ Soc Clin Microbiol Infect Dis 2007. [DOI:10.1016/S0924-8579(07)71682-5]
14. Krashias G, Bashiardes S, Potamitou A, Potamitis GS, Christodoulou Ch. Prevalence of Helicobacter pylori CagA and vacA genes in Cypriot patients. J Infect Dev Ctries 2012; 7(9):642-650. [DOI:10.3855/jidc.2923] [PMID]

15. Hussein NR, Mohammadi M, Talebkhan Y, Doraghi M, Letley DP, Muhammad MK, et al. Differencesin virulence markers between Helicobacter pylori strains from Iraq and those from Iran: potential importance of regional differences in H. pylori-associated disease, Journal of Clinical Microbiology 2008; 46(5): 1774-1779. [DOI:10.1128/JCM.01737-07]

16. Essawi T, Hammoudeh W, Sabri I, Sweidan W, and Farraj M A. Determination of Helicobacter pylori Virulence Genes in Gastric Biopsies by PCR. Hindawi Publishing Corporation ISRN Gastroenterology 2013; 16:119-123. [DOI:10.1155/2013/606258] [PMID] [PMCID] 


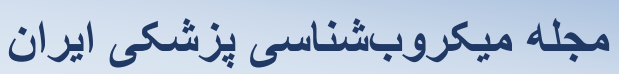

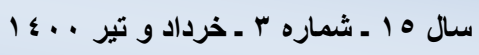 \\ Journal homepage: www.ijmm.ir}

شيوع زن cagAهليكوباكتر يِيلورى در بيماران مبتلا به زخم معده

\section{فاطمه كشاورزى"(D)، شعله ميرزايى'، يرمان كرمى'}

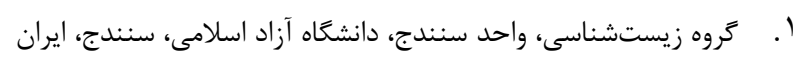

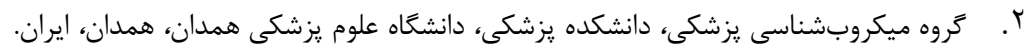

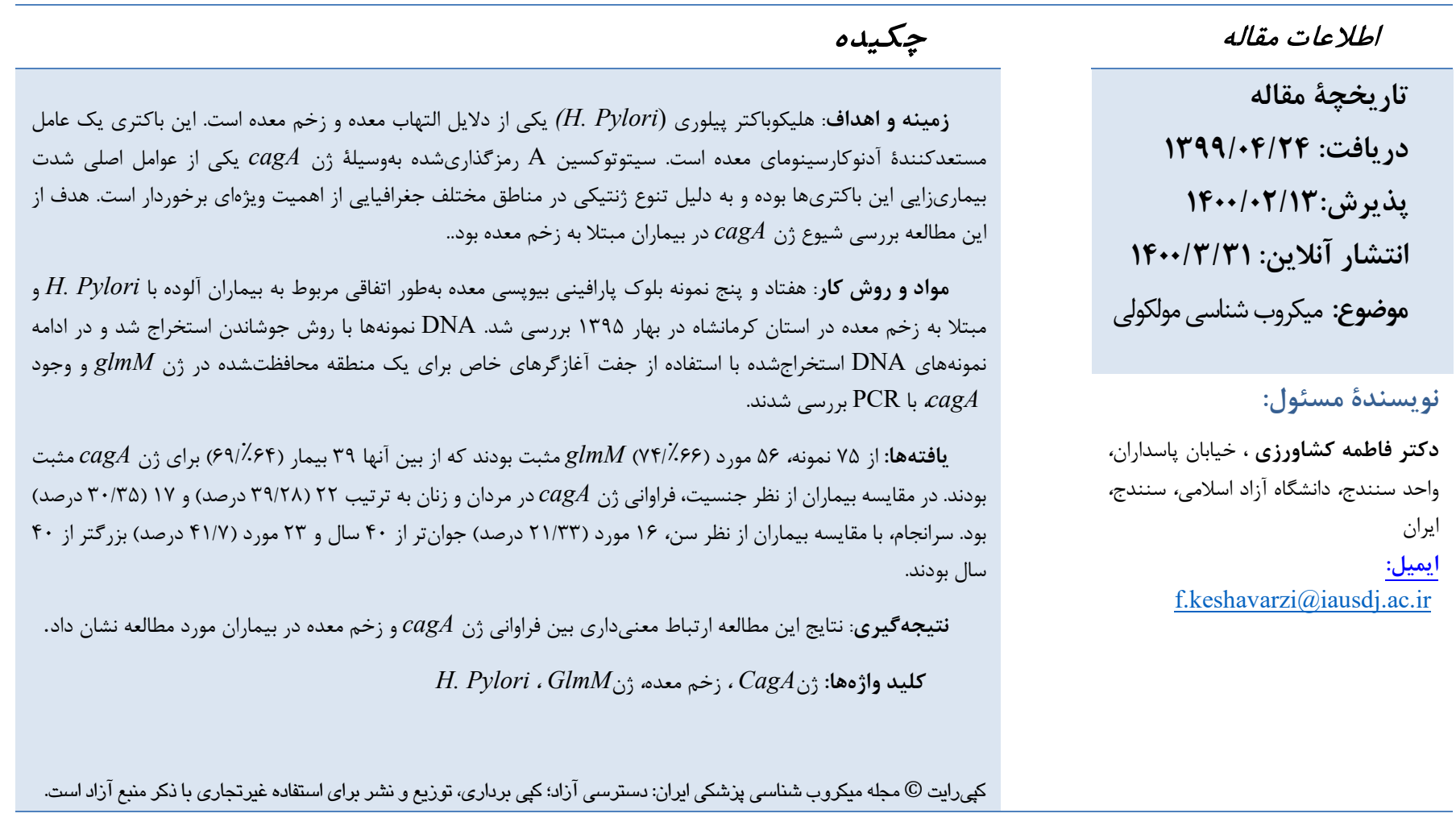

